
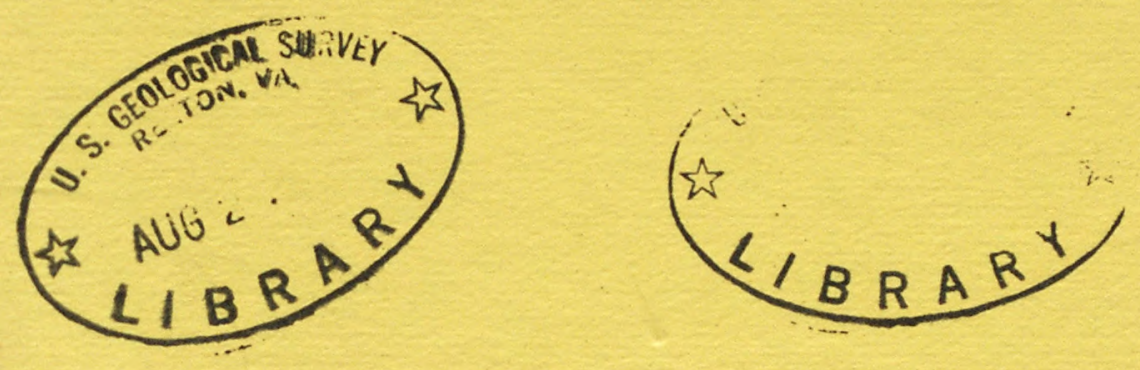

\title{
Analysis of Street Sweepings, Portland, Oregon
}

\author{
U.S. GIOI OGICAL SURVEY \\ Open File Report
}

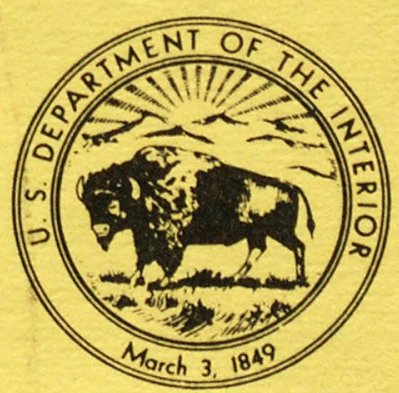

Prepared in cooperation with the

U.S. Army Corps of Engineers 


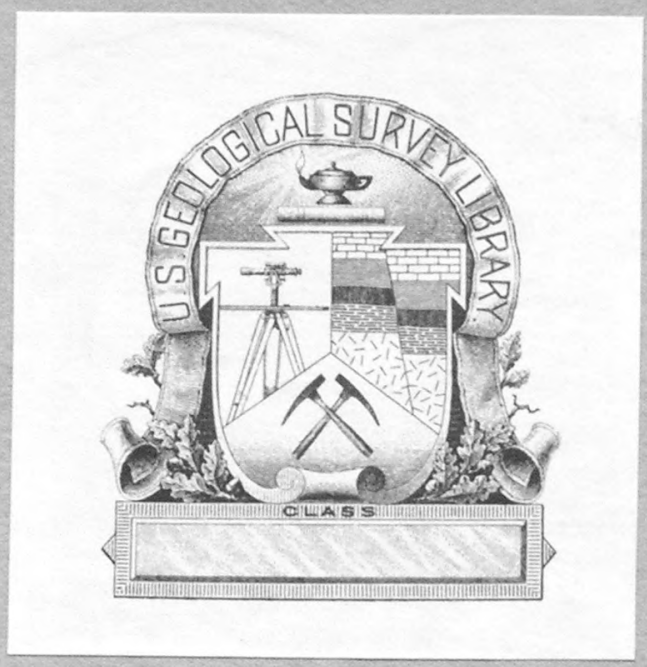


ANALYSIS OF STREET SWEEPINGS, PORTLAND, OREGON

By Timothy L. Miller, Joseph F. Rinella, Stuart W. McKenzie, and Jerry Parmenter

U.S. GEOLOGICAL SURVEY

Open-File Report

Prepared in cooperation with the

U.S. Army Corps of Engineers

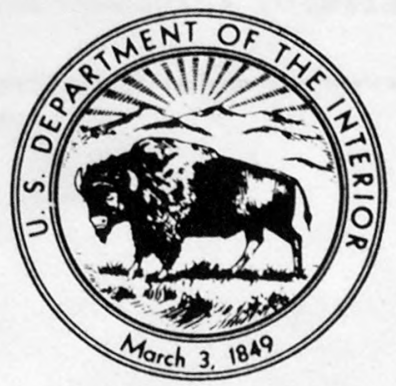


UNITED STATES DEPARTMENT OF TIIE INTERIOR

Cecil D. Andrus, Secretary

GEOLOGICAL SURVEY

Vincent E. McKelvey, Director

For additional information write to:

U.S. Geological Survey

P.O. Box 3202

Portland, Oregon 97208

0

och

$10|3| 17$ 
CONTENTS

Page

Abstract-10.0. 1

Introduction-1..- 2

Site selection, sampling, and analytical determination-... 3

Description of sampling plots-1 5

Analysis methodology

Results-1 14

References-15

\section{ILLUSTRATION}

Figure 1. Locations of street-sweeping sites, streamflow stations, and rain gages-a.- 4

\section{TABLES}

Table 1. Analysis of street-sweeping materia1 8

2. $\mathrm{BOD}_{\mathrm{u}}$ of street material 


\section{CONVERSION FACTORS}

The following factors may be used to convert the English units published here to the International System of Units (SI).

\begin{tabular}{l|c|c}
\hline \multicolumn{1}{c|}{ English } & Multiply by & Metric (SI) \\
\hline inches (in) & 25.4 & millimeters (mm) \\
\hline square miles $\left(\mathrm{mi}^{2}\right)$ & 2.590 & square kilometers (km ${ }^{2}$ ) \\
\hline
\end{tabular}


ANALYSIS OF STREET SWEEPINGS, PORTLAND, OREGON

By Timothy L. Miller, Joseph F. Rine1la, Stuart W. McKenzie, and Jerry Parmenter $1 /$

\section{ABSTRACT}

A brief study involving collection and analysis of street sweepings was undertaken to provide the U.S. Army Corps of Engineers with data on physical, chemical, and biological characteristics of dust and dirt accumulating on Portland streets. Most of the analyses selected were based on the pollutant loads predicted by the Storage, Treatment, Overflow, and Runoff Model (STORM). Five different basins were selected for sampling, and samples were collected three times in each basin. Because the 1iterature reports no methodology for analysis of dust and dirt, the analytical methodology is described in detail. Results of the analyses are summarized in table 1. 


\section{INTRODUCTION}

The U.S. Geological Survey, in cooperation with the U.S. Army Corps of Engineers and the Columbia Region Association of Governments (CRAG), is studying the quantity and quality of urban storm water in the Portland area. The study includes collecting data on rainfa11, volume of runoff, and water quality from seven basins in the study area. These basins are described in detail in Geological Survey OpenFile Report 76-954 (McKenzie and Miller, 1976). A11 data collected from the basins are to be used by the Corps of Engineers, Portland District, to calibrate their Storage, Treatment, Overflow, and Runoff Mode1 (STORM).

One necessary input to the model is the pollutant-accumulation rate. STORM has two methods for specifying pollutant accumulation: (1) the daily accumulation method and (2) the dust and dirt method. The daily pollutant-accumulation method used for rural watersheds assumes that pollutants come from areas other than streets and that dust and dirt accumulation rates are not needed. The dust and dirt method is applied to urban areas, assuming that streets with gutters exist and all pollutants are associated with dust and dirt accumulation (U.S. Army Corps of Engineers, 1976). "Default values" present1y used in STORM for dust and dirt accumulation rates and associated pollutant concentrations are from a 1968 Chicago study (Am. Public Works Assoc., 1969). "Default values," as used here, relate to the numerical values in STORM, specifying the rate of accumulation of dust and dirt that the model will use if local values are not provided. 
The Geological Survey, in cooperation with the Corps of Engineers, analyzed a small number of samples to determine physical, chemical, and bacterial characteristics of dust and dirt accumulating on streets in the Portland area. The study was undertaken to enable the Corps of Engineers to determine whether dust and dirt from streets in Portland is significantly different from that in Chicago.

SITE SELECTION, SAMPLING, AND ANALYTICAL DETERMINATIONS

Because the dust and dirt method applies to the study area for which the Geological Survey has been collecting water-quality and water-quantity data, four of the seven monitored basins were chosen for dust and dirt collection. Two basins were selected on the east side of the Willamette River and two on the west side. A fifth basin was selected to provide a high percentage of impervious area. This basin was monitored by the city of Portland and is about 95 percent impervious. The basins sampled are shown in figure 1.

The two basins monitored by the Geological Survey west of the Willamette River are Fanno Creek (drainage area $2.37 \mathrm{mi}^{2}$ ) and the tributary to Beaverton Creek at Murray Boulevard (drainage area $0.21 \mathrm{mi}^{2}$ ). The two basins east of the Willamette are Kelly Creek (drainage area $4.16 \mathrm{mi}^{2}$ ) and the tributary to the Willamette River at Oak Grove (drainage area $0.74 \mathrm{mi}^{2}$ ). The basin monitored by the city of Portland is an unnamed combined-sewered drainage (drainage area $0.37 \mathrm{mi}^{2}$ ) sampled at Union Avenue and Davis Street just east of the Willamette River. 


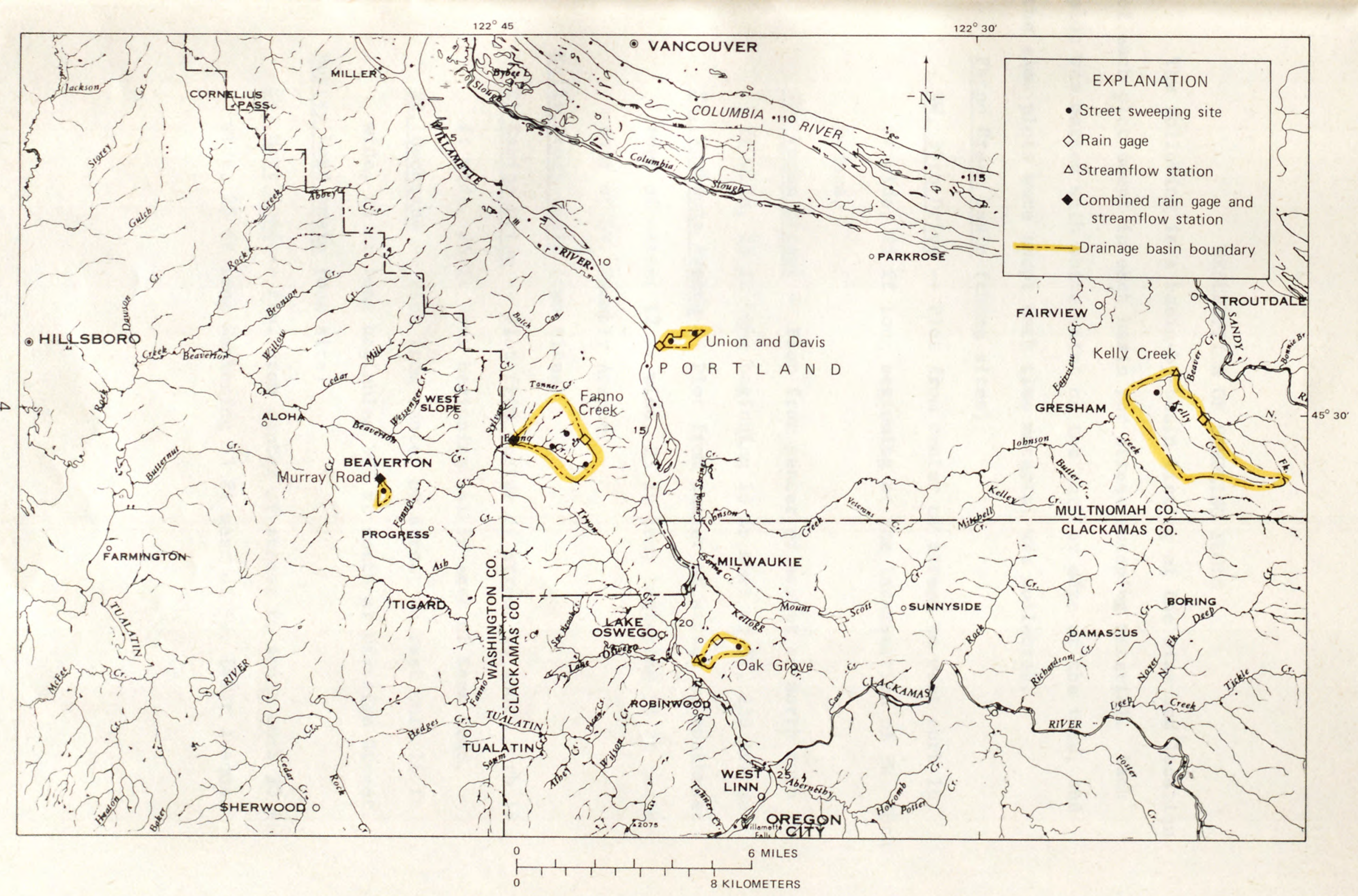

Figure 1. - Locations of street sweeping sites, streamflow stations, and rain gages. 
DESCRIPTION OF SAMPLING PLOTS

The following is a basin-by-basin listing of the size and location of each plot swept in each basin for street-sweeping material. Each plot was marked with white paint on the curb or edge of the road, and the same plots were swept each time material was collected.

Fanno Creek basin (three sites)

SW. 39th Drive -- Plot from center of street to west curb 16 ft wide, $25 \mathrm{ft}$ long beginning at the intersection of SW. 38th Avenue.

SW. Kanan Street -- P1ot from center of street to north curb 18 ft wide, $25 \mathrm{ft}$ long beginning $16 \mathrm{ft}$ west of SW. 23d Avenue.

SW. Washouga Avenue -- P1ot from center of street to southwest edge of street $12 \mathrm{ft}$ wide, $25 \mathrm{ft}$ long beginning $55 \mathrm{ft}$ southeast of SW. Twombly Avenue.

Ke11y Creek basin (two sites)

E1 Camino Drive -- Plot from center of street to south curb 18 ft wide, $25 \mathrm{ft}$ long beginning $141 \mathrm{ft}$ east of Kane Road. NE. Cochrane -- Plot from center of street to east curb $16 \mathrm{ft}$ wide, $25 \mathrm{ft}$ long beginning $305 \mathrm{ft}$ north of Division Street. Murray Road basin (one site)

SW. Hart Road -- Plot from center of street to south curb $20 \mathrm{ft}$ wide, $25 \mathrm{ft}$ long beginning $53 \mathrm{ft}$ west of SW. 141st Avenue. 
Oak Grove basin (two sites)

SE. Crewswain Avenue -- Plot from center of street to west curb $14 \mathrm{ft}$ wide, $25 \mathrm{ft}$ long beginning $140 \mathrm{ft}$ southeast of SE. Creighton Avenue.

SE. Hager Lane -- Plot from center of street to southwest curb $16 \mathrm{ft}$ wide, $25 \mathrm{ft}$ long beginning $300 \mathrm{ft}$ from edge of $\mathrm{SE}$. Risley Avenue.

Union Avenue and Davis Street basin (two sites)

NE. 10th Avenue -- P1ot from center of street to east curb $18 \mathrm{ft}$ wide, 25 ft long beginning $12 \mathrm{ft}$ south of NE. Everett Street. NE. 25th Avenue -- Plot from center of street to the east curb $12 \mathrm{ft}$ wide, $25 \mathrm{ft}$ long beginning $69 \mathrm{ft}$ south of NE. Oregon Street.

Sampling plots on streets were selected to reflect different land uses within the basin and different basin sizes. The number of different plots swept ranged from one plot in the smallest basin to three plots in Fanno Creek basin. The sweepings from each plot were composited into one bag for the basin. Samples were collected by hand sweeping rather than by vacuuming because vacuuming may agglomerate particles, and it would be difficult to remove very fine particles from the vacuum for analysis. Street-sweeping material was collected by the Corps of Engineers, Portland District, and delivered in large plastic bags to the Geological Survey for analysis.

Each plot was sampled three times. The last sample in each basin was collected after a dry period of at least 2 weeks. 
The analytical determinations made for each dust and dirt sample included: total dry sample weight, dry sieving, percent moisture, percent ash, percent settleable solids, biochemical oxygen demand (BOD), total phosphorus, total nitrogen, and indicator bacteria analysis. A few samples were selected for lead and zinc analysis. The total sample weight provides information on dust and dirt accumulation rates. The percent moisture allowed all samples to be compared on a dry-weight basis. In sieving, the samples were broken into two size fractions, greater than or equal to $(\geqslant)$ and less than $(<) 2$ millimeters $(\mathrm{mm})$. The 2-mm size was selected because it did not seem reasonable that particles greater than $2 \mathrm{~mm}$ could be washed from the street to the stream with the low-intensity rainfal1 commonly experienced in the Portland area. Percent ash provides an estimate for determining the percentage of organic material in the sample. Each of the remaining analyses (settleable solids, BOD, indicator bacteria analysis, total phosphorus, and total nitrogen) was included because STORM predicts loads for those constituents.

\section{ANALYSIS METHODOLOGY}

Upon receipt of street-sweeping samples, analyses were either started immediately or the samples were stored at $4^{\circ} \mathrm{C}$ for a period not exceeding 24 hours.

Tota1 dry-sample weight.--The total wet weight of the sample was determined by weighing the sample and bag and then subtracting the weight of the empty plastic bag. This weight was corrected for moisture later in the analysis. Weights were measured to the nearest gram. 
Table 1. Analysis of street-sweeping material

\begin{tabular}{|c|c|c|c|c|c|c|c|c|c|c|c|c|c|c|c|c|c|c|}
\hline \multirow[b]{2}{*}{ Site } & \multirow[b]{2}{*}{ Date } & \multirow[b]{2}{*}{$\begin{array}{l}\text { Total } \\
\text { sample } \\
\text { area } \\
\left(\mathrm{ft}^{2}\right) \\
\end{array}$} & \multirow[b]{2}{*}{$\begin{array}{l}\text { Antece- } \\
\text { dent } \\
\text { dry } \\
\text { days }\end{array}$} & \multirow[b]{2}{*}{$\begin{array}{l}\text { Total } \\
\text { dry } \\
\text { sample } \\
\text { weight } \\
\text { (grams) } \\
\end{array}$} & \multicolumn{2}{|c|}{ Sample $\geq 2 \mathrm{~mm}$} & \multicolumn{12}{|c|}{ Sample < $2 \mathrm{~mm}$} \\
\hline & & & & & $\begin{array}{l}\text { Percent } \\
\text { total } \\
\text { dry } \\
\text { sample }\end{array}$ & $\begin{array}{l}\text { Percent } \\
\text { moisture }\end{array}$ & $\begin{array}{c}\text { Percent } \\
\text { total } \\
\text { dry } \\
\text { sample } \\
\end{array}$ & $\begin{array}{l}\text { Percent } \\
\text { moisture }\end{array}$ & $\begin{array}{c}\text { Percent } \\
\text { ash }\end{array}$ & $\begin{array}{c}\text { Percent } \\
\text { settle- } \\
\text { able } \\
\text { solids }\end{array}$ & $\begin{array}{c}\mathrm{BOD}_{\mathrm{u}} \\
(\mathrm{g} / \mathrm{kg})\end{array}$ & $\begin{array}{c}\mathrm{BOD}_{5} \\
(\mathrm{~g} / \mathrm{kg}) \\
\end{array}$ & $\begin{array}{l}\text { Total P } \\
(\mathrm{mg} / \mathrm{kg})\end{array}$ & $\begin{array}{l}\text { Total N } \\
(\mathrm{mg} / \mathrm{kg})\end{array}$ & $\begin{array}{c}\text { Fecal } \\
\text { coliform } \\
\text { (colonies } \\
(\mathrm{kg})\end{array}$ & $\begin{array}{c}\text { Fecal } \\
\text { strepto- } \\
\text { cocci } \\
\text { (colonies } \\
\text { (kg) }\end{array}$ & $\begin{array}{c}\text { Lead } \\
\text { (ug/g) }\end{array}$ & $\begin{array}{l}\text { Zinc } \\
(\mathrm{ug} / \mathrm{g}) \\
\end{array}$ \\
\hline Fanno Creek & $3-11-76$ & 1,162 & 13 & 4,807 & 15.8 & 2.7 & 84.2 & 2.6 & 91.9 & 99.0 & 12.1 & 2.4 & 580 & 1,100 & $<7.2 \times 10^{3}$ & $5.1 \times 10^{4}$ & 670 & 147 \\
\hline do & $3-30-76$ & 1,162 & 6 & 7,038 & 26.8 & 2.4 & 73.2 & 1.5 & 93.9 & 98.9 & 10.3 & 2.0 & 390 & 1,130 & $<7.1 \times 10^{3}$ & $1.3 \times 10^{5}$ & -- & -- \\
\hline do & $6-29-76$ & 1,162 & 14 & 2,598 & 39.0 & 1.8 & 61.0 & 1.9 & 85.4 & 96.0 & 60.4 & 12.0 & 270 & 5,600 & $1.5 \times 10^{7}$ & $4.0 \times 10^{7}$ & -- & -- \\
\hline Kelly Creek & $3-10-76$ & 850 & 12 & 4,811 & 11.5 & 4.3 & 88.5 & 1.5 & 96.2 & 99.6 & 5.6 & 1.1 & 550 & 620 & $<7.1 \times 10^{3}$ & $1.7 \times 10^{4}$ & 820 & 176 \\
\hline do & $3-30-76$ & 850 & 4 & 2,514 & 9.5 & 2.4 & 90.5 & 1.5 & 96.1 & 99.4 & 7.3 & 1.4 & 430 & 1,170 & $<7.1 \times 10^{3}$ & $8.1 \times 10^{3}$ & -- & -- \\
\hline do & $6-29-76$ & 850 & 14 & 1,682 & 9.1 & 1.9 & 90.9 & 1.1 & 93.7 & 97.7 & 21.7 & 4.6 & 130 & 1,500 & $1.1 \times 10^{4}$ & $1.7 \times 10^{6}$ & -- & $\cdots$ \\
\hline Murray Road & $3-12-76$ & 500 & 13 & 3,497 & 24.5 & 5.2 & 75.5 & 3.4 & 94.9 & 96.9 & 11.8 & 2.4 & 810 & 740 & $<4.3 \times 10^{3}$ & $2.5 \times 10^{4}$ & 1.000 & 182 \\
\hline do & $3-30-76$ & 500 & 6 & 2,006 & 11.3 & 2.6 & 88.7 & 1.8 & 95.9 & 98.4 & 9.3 & 1.8 & 290 & 1,210 & $<7.1 \times 10^{3}$ & $1.6 \times 10^{4}$ & - & $-\cdot$ \\
\hline do & $6-29-76$ & 500 & 14 & 162 & 41.7 & 2.9 & 58.3 & 1.8 & 81.1 & 93.0 & 63.3 & 12.8 & 240 & 3,750 & $1.1 \times 10^{5}$ & $7.6 \times 10^{6}$ & $\cdots$ & $-\cdot$ \\
\hline Oak Grove A & $3-9-76$ & 750 & 12 & 885 & 35.3 & 29.9 & 64.7 & 24.3 & 73.9 & 98.1 & 50.9 & 10.2 & 540 & 3,500 & $9.4 \times 10^{3}$ & $9.4 \times 10^{5}$ & 740 & 154 \\
\hline Oak Grove B & $3-9-76$ & & & 1,093 & 37.3 & 30.8 & 62.7 & 23.1 & 75.8 & 97.8 & 43.6 & 8.7 & 530 & 3,100 & $4.9 \times 10^{4}$ & $2.0 \times 10^{6}$ & 760 & 148 \\
\hline Oak Grove & $3-30-76$ & 750 & 5 & 1,178 & 28.4 & 23.0 & 71.6 & 17.1 & 78.0 & 95.2 & 77.8 & 15.5 & 400 & 4,650 & $<8.4 \times 10^{3}$ & $1.8 \times 10^{6}$ & $-\cdot$ & -- \\
\hline do & $6-29-76$ & 750 & 14 & 1,577 & 13.0 & 2.4 & 87.0 & 2.9 & 80.9 & 96.3 & 68.8 & 13.9 & 160 & 6,500 & $6.2 \times 10^{4}$ & $3.1 \times 10^{6}$ & - & -- \\
\hline Union and Davis A & $3-30-76$ & 750 & 5 & 1,140 & 4.9 & 6.7 & 95.1 & 3.7 & 93.4 & 99.0 & 13.7 & 2.9 & 220 & 1,680 & $<7.3 \times 10^{3}$ & $2.5 \times 10^{4}$ & $-\cdot$ & $\cdots$ \\
\hline Union and Davis B & $3-30-76$ & & & 1,097 & 4.3 & 7.8 & 95.7 & 3.7 & 93.2 & 98.3 & 13.2 & 2.7 & 234 & 2,100 & $<7.3 \times 10^{3}$ & $8.6 \times 10^{4}$ & - & -- \\
\hline Union and Davis & $6-29-76$ & 750 & 14 & 1,197 & 8.1 & 0 & 91.9 & 1.1 & 92.1 & 97.5 & 25.7 & 5.2 & 84 & 2,760 & $1.5 \times 10^{5}$ & $6.6 \times 10^{6}$ & - & $-\cdot$ \\
\hline do & $7-28-76$ & 750 & 21 & 999 & 7.6 & 1.3 & 92.4 & 1.5 & 88.4 & 98.2 & 30.8 & 11.3 & 390 & 2,600 & $<7.1 \times 10^{3}$ & $2.1 \times 10^{6}$ & -- & -- \\
\hline
\end{tabular}


Sieving and percent moisture.--The total sample was dry sieved and separated into two sizes, materia $1 \geqslant 2 \mathrm{~mm}$ and materia $1<2 \mathrm{~mm}$. Each portion was weighed after sieving. The entire $\geqslant 2-m m$ portion was then dried at $105^{\circ} \mathrm{C}$ for at least 24 hours and reweighed to determine the percent moisture. No further analysis was done on the $<2-\mathrm{mm}$ portion.

A subsample of the $<2-m$ m portion (100 to 150 grams) was dried following the same procedure to determine percent moisture. The total dry-sample weight 1 isted in table 1 is thus equal to the $\geqslant 2-m m$ dry weight plus the $<2-\mathrm{mm}$ wet weight corrected for moisture content.

Percent ash.--Percent ash was determined using a 4- to 6-gram subsample of $<2-\mathrm{mm}$ material that had already been dried. The sample was ignited in a muffle furnace at $500^{\circ} \mathrm{C}$ for 30 minutes and then removed, cooled, and reweighed. The volatile-solids content of the sample equa1s 100 percent minus percent ash. The organic material may be less than or equal to the volatile solids.

Settleable solids. --A 10-gram subsample of the $<2$-mm wet material was mixed with 1 liter of distilled water and placed in an Imhoff cone. After 1 hour of settling (Am. Public Health Assoc., 1975), the volume of settled material was measured in milliliters per liter. The weight of dried settled material was used to calculate the percent settleable solids. 
Biochemical oxygen demand (BOD), u1timate and 5-day.--Subsamples of the $<2-\mathrm{mm}$ wet material were placed directly in BOD bottles and mixed with Willamette River water. Willamette River water was used for two reasons. First, the water already contains a bacterial seed needed for the BOD test. Second, the Willamette River is the major receiving stream for most of the basins sampled. Therefore, using Willamette water gives some indication of the effect that street material might have on the river water. A minimum of three bottles containing only river water was used as blanks for each set of BOD analyses. A11 samples were incubated at $20^{\circ} \mathrm{C}$ for approximately 20 days, with dissolved oxygen (DO) readings taken frequently enough to measure $B O D$ reaction rate and to ensure that the DO concentration remained more than 2 milligrams per 1 iter (mg/L). When the DO concentration approached $2 \mathrm{mg} / \mathrm{L}$ or would drop below that level by the next reading date, the sample was reaerated to increase the DO concentration.

A Yellow Springs Instrument Mode1 54늘 DO meter and stirring BOD bottle probe were used in measuring DO. The 5-day and ultimate BOD values $\left(\mathrm{BOD}_{5}, \mathrm{BOD}_{\mathrm{u}}\right)$ were determined after subtracting the $\mathrm{BOD}$ due to the river water in a manner consistent with that reported in Geological Survey Circular 715-I (Hines and others, 1977).

1/ The use of brand names in this report is for identification purposes only and does not imply endorsement by the U.S. Geological Survey. 
The sizes of street-sweeping subsamples used in the BOD test are 1isted across the top of table 2. The values recorded in table 2 are $\mathrm{BOD}_{\mathrm{u}}$ per gram dry weight of street-sweeping material. Results of duplicate samples are listed as two values under the same subsample size for the given date. Table 2 indicates that as the size of the subsample is decreased, the $\mathrm{BOD}_{\mathrm{u}}$ per gram of subsample increases. This phenomenon may have resulted from the material being too concentrated for the bacterial seed provided by the river water, or the bacterial seed was inhibited by heavy metals. Because of the problem of lower BOD in more concentrated samples and because it was difficult to ensure that the DO remained more than $2 \mathrm{mg} / \mathrm{L}$ in the BOD bottles with 10-gram subsamples, the 3- and 10-gram samples were not used to calculate BOD values.

The values used to calculate sample $\mathrm{BOD}_{\mathrm{u}}$ and $\mathrm{BOD}_{5}$ were selected on the basis of one of the following criteria: (1) A combination of two or more BOD values coming from different size subsamples that yield about the same $\mathrm{BOD}_{\mathrm{u}}$ per gram of street material, or (2) values that yield the highest $\mathrm{BOD}_{\mathrm{u}}$ on a per gram basis. The first criterion was used whenever possible as the preferred method of computing the sample $\mathrm{BOD}_{\mathrm{u}}$ and $\mathrm{BOD}_{5}$. If the sample $\mathrm{BOD}_{\mathrm{u}}$ and $\mathrm{BOD}_{5}$ was calculated from a combination of bottles with different size subsamples, the calculation was weighted according to subsample size. More significance was given to larger subsample bottle values because it was difficult to ensure that the smaller subsamples (for example, 0.1-gram subsample) were representative samples. 
Table 2.- BOD $_{\mathrm{u}}$ (in grams per kilogram of dry weight) of street material

\begin{tabular}{|c|c|c|c|c|c|}
\hline \multirow[b]{2}{*}{ Site and date } & \multicolumn{5}{|c|}{ Wet sample weight, in grams } \\
\hline & 10 & 3 & 1 & 0.3 & 0.1 \\
\hline Fanno Creek, 3-11-76 & 3.7 & 8.2 & $12.1 *$ & -- & -- \\
\hline Fanno Creek, 3-30-76 & -- & - & $10.1 *$ & $11.3 *$ & $8.8 *$ \\
\hline Fanno Creek, 6-29-76 & -- & -- & -- & $\begin{array}{l}(55.2 \% \\
(65.6 *\end{array}$ & -- \\
\hline Ke11y Creek, 3-10-76 & 3.0 & 4.7 & $5.7 *$ & $5.3 *$ & -- \\
\hline Ke11y Creek, 3-30-76 & -- & 6.5 & $7.1 *$ & $7.6 *$ & $8.5 *$ \\
\hline Ke11y Creek, 6-29-76 & -- & -- & $21.0 *$ & $25.3 *$ & $17.9 *$ \\
\hline Murray Road, 3-12-76 & 6.9 & 7.7 & $11.8 *$ & -- & -- \\
\hline Murray Road, 3-30-76 & -- & -- & $8.8 *$ & $7.3 *$ & $19.6 *$ \\
\hline Murray Road, 6-29-76 & -- & -- & 35.7 & $\begin{array}{l}(48.6 * \\
(78.0 *\end{array}$ & -- \\
\hline Oak Grove A, 3-9-76 & -- & 23.7 & 32.9 & $50.9 *$ & -- \\
\hline Oak Grove B, 3-9-76 & -- & 24.2 & 33.2 & $43.5 *$ & -- \\
\hline Oak Grove, 3-30-76 & -- & -- & 50.8 & $74.8 *$ & $86.5 *$ \\
\hline Oak Grove, 6-29-76 & -- & -- & 50.5 & $\begin{array}{l}(71.6 * \\
(66.0 \%\end{array}$ & -- \\
\hline Union and Davis $A, 3-30-76$ & - & -- & $13.8 *$ & $13.2 *$ & $14.9 *$ \\
\hline Union and Davis B, 3-30-76 & -- & -- & $12.8 *$ & $13.7 *$ & $16.5 *$ \\
\hline Union and Davis, 6-29-76 & -- & -- & $25.6 *$ & $24.3 *$ & $31.2 \%$ \\
\hline Union and Davis, 7-28-76 & -- & -- & 18.8 & $29.6 *$ & $34.4 *$ \\
\hline
\end{tabular}

* Indicates values used to calculate sample $\mathrm{BOD}_{\mathrm{u}}$ and $\mathrm{BOD}_{5}$. 
Indicator bacteria analysis.--Ten grams of the original undried $<2-\mathrm{mm}$ street material was mixed with 1 iter of distilled water. The $\mathrm{pH}$ of the distilled water was measured to be between 6.5 and 7.0 units. The mixture was stirred constantly during subsampling for filtering, using a magnetic stirrer. For fecal coliform, sample volumes of 1,3 , and $10 \mathrm{~mL}$ were filtered and incubated following procedures in the Geological Survey Techniques of Water-Resources Investigations Book 5, Chapter A4 (S1ack and others, 1973). Sample volumes of $0.4,2$, and 10 $\mathrm{mL}$ were filtered for fecal streptococci and incubated following procedures as above (Slack and others, 1973). The fecal coliform filters were incubated on $\mathrm{M}-\mathrm{FC}$ agar and the fecal streptococci filters were incubated on M-Enterococcus agar. Colonies were counted with the use of a microscope with magnification of $15 x$ or $45 x$. On many of the fecal coliform plates, no colonies were found. A larger sample volume was not filtered on the $47-\mathrm{mm}$ filter because of the amount of debris. Because of the difficulty in trying to obtain fecal coliform colonies on the 47-mm filters, larger filters were a1so used for the last set of street-sweeping samples collected. In addition to the previously mentioned volumes filtered on the 47-mm filters, volumes of 30 and 100 $\mathrm{mL}$ were filtered on 102-mm filters and incubated with the smaller filters. Countable colonies did develop on the larger filters, which helped to achieve the ideal 20 to 60 and 20 to 100 colony counts for fecal coliform and fecal streptococci, respectively.

Total phosphorus and total nitrogen. --The $<2$-mm wet sample material was sent to the U.S. Geological Survey's central laboratory for determination of phosphorus and nitrogen concentration. 


\section{RESULTS}

Table 1 is a summary of the analyses of the dust and dirt samples. Samples that are marked A and B are duplicate samples obtained by sieving the entire sample, then subdividing the sample approximately in half and running the analyses on halves A and B independently. A11 values shown in table 1 were calculated on a dry-weight basis.

Additional data in table 1 include the total street area swept for each sample and the number of days that elapsed since a storm with rainfall intensity of at least 0.25 inch in 6 hours.

Dust and dirt or individual constituent accumulation rates are not calculated in this report, and the user of these data is cautioned against making such calculations or comparing the data with those in the Chicago (Am. Public Health Assoc., 1969), Omaha (U.S. Army Corps of Engineers, 1975), or Enviromenta1 Protection Agency (Sartor and Boyd, 1972) reports for the following reasons: (1) The method of removing the material from the street was not consistent between studies, analysis methodology varied between studies, and (3) the data in this study are insufficient to calculate accumulation rates because no data are provided on street-cleaning practices or frequency. 
REFERENCES

American Public Health Association and others, 1975, Standard methods for the examination of water and wastewater [14th ed.]: Washington, D. C., Am. Public Health Assoc., 1193 p. American Pub1ic Works Association, 1969, Water pollution aspects of urban runoff, in Water Pollution Contro1 Research Series: Federa1 Water Pollution Control Adm. Rept. WP-20-15.

Hines, W. G., McKenzie, S. W., Rickert, D. A., and Rine1la, F. A., 197_, Dissolved-oxygen regimen of the Willamette River, Oregon, under conditions of basinwide secondary treatment: U.S. Geol. Survey Circ. 715-I (in review).

McKenzie, S. W., and Miller, T. L., 1976, Basic data on urban stormwater quality, Portland, Oregon: U.S. Geo1. Survey Open-File Rept. 76-594, 71 p.

Sartor, J. D., and Boyd, G. B., 1972, Water pollution aspects of street surface contaminants: U.S. Environmental Protection Agency, Office of Research and Monitoring Rept. EPA-R2-72-081; available from Washington, D.C., U.S. Govt. Printing Office, 236 p. S1ack, K. V., Averett, R. C., Greeson, P. E., and Lipscomb, R. G., 1973, Methods for collection and analysis of aquatic biological and microbiological samples: U.S. Geol. Survey Techniques WaterResources Inv., book 5, chap. A4, 165 p. 
U.S. Army Corps of Engineers, 1975, Urban street pollutant analysis:

Omaha, Nebr., U.S. Army Engineer Dist., 103 p.

1976, Storage, Treatment, Overflow, Runoff Mode1 "STORM":

Computer program 723-S8-L7520 Users Manua1, 167 p. 
